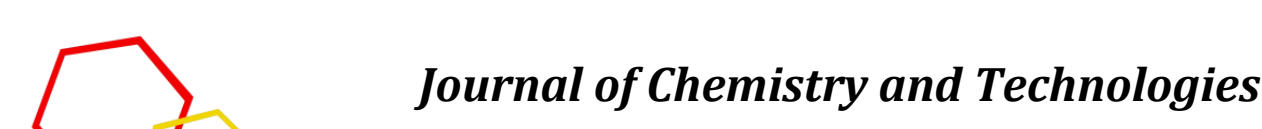

pISSN 2663-2934 (Print), ISSN 2663-2942 (Online)

journal homepage: http://chemistry.dnu.dp.ua

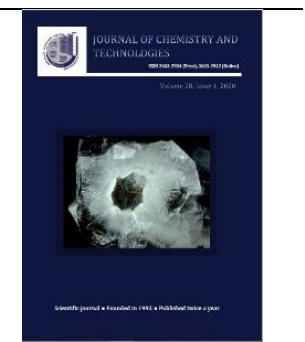

\author{
UDC 637.07:579.678 \\ PROBLEMS OF THE DAIRY AND MEAT INDUSTRY MARKET. MONITORING THE SPREAD \\ OF ANTIBIOTIC-RESISTANT STRAINS OF SANITARY-INDICATIVE MICROFLORA \\ Tetiana V. Sklyar ${ }^{1}$, Kateryna V. Lavrentieva1 ${ }^{1}$, Olena A. Lykholat ${ }^{1}$, Natalya V. Kondratjuk ${ }^{1}$, \\ Kateryna Ye. Suprunenko1, Tetiana M. Stepanova ${ }^{2}$ \\ 1Oles Honchar Dnipro National University, 72 Gagarina Ave., Dnipro, 49000, Ukraine \\ ${ }^{2}$ Sumy National Agrarian University, 160 Gerasyma Kondratiyeva St., Sumy, 40021, Country \\ Received 1 May 2020; accepted 7 July 2020; available online 16 July 2020
}

\title{
Abstract
}

This article presents a study of monitoring the spread of antibiotic-resistant strains of sanitary-indicative microflora of food products sold on the consumer market of Dnipropetrovsk region.

The increase of population in the world leads to an increase in the quality of livestock and poultry products. World experience shows that it is impossible to abandon the use of antibiotics in the rearing of pigs, cattle and poultry. Firstly, it is related to therapeutic and preventive measures in the fight against various diseases. Secondly, due to biochemical transformations in muscle fibers with the participation of antibiotics, consumer quality indicators (color, consistency) and technological quality indicators (moisture-absorbing and moisture-retaining ability) are improved. Therefore, livestock products can be one of the sources of sanitary microflora entering into the human body. In addition to the ability to cause an infectious process due to the synthesis of various pathogenic factors, including enzymes, toxins, adhesion substances, etc., in the sanitary-indicative microflora there is interstitial, intraspecific and intergeneric transfer of antibiotic resistance genes. This contributes to the emergence of cultures with acquired resistance to antibiotics and the formation of multi-resistant variants. Elimination of such strains from the human body will present certain difficulties.

It was found that in the studied samples of milk and dairy products, as well as meat and offal of cattle and poultry, representatives of coliform bacteria, staphylococci and enterococci were less common. The isolated strains of sanitary-indicative microflora were the most resistant to ampicillin, oxacillin, tetracycline and doxycillin. 10 strains of S. aureus and 7 strains of S. epidermidiswas classified as MRSA and MRSE, respectively. Five of them were resistant to vancomycin and three to linezolid. Among the isolated cultures of enterococci were strains that were resistant to 5-6 or more drugs simultaneously. Of the bacteria of the family Enterobacteriaceae, the ability to synthesize extended-spectrum beta-lactamase (ESBL) was detected in 18 cultures, which accounted for $25.0 \%$ of the total number of opportunistic enterobacteria. The ESBL strains of bacteria of the family Enterobacteriaceae differed from other isolates by resistance to at least 4 antibiotics, among which at least one belonged to the group of thirdgeneration cephalosporins. 7 strains of Escherichia coli, two strains of $P$. vulgaris and three strains of $K$. pneumoniae were characterized by resistance to 6 or more tested drugs.

Keywords: meat products; dairy products; antibiotic resistance; bacterium of intestinal bacillus; Staphylococcus aureus; Staphylococcus epidermidis; Enterobacter cloaceae; Klebsiella pneumoniae; Proteus vulgaris.

\section{ПРОБЛЕМИ РИНКУ МОЛОЧНОЇ ТА М'ЯСНОЇ ПРОМИСЛОВОСТІ. МОНІТОРИНГ РОЗПОВСЮДЖЕННЯ АНТИБІОТИКОРЕЗИСТЕНТНИХ ШТАМІВ САНІТАРНО- ПОКАЗОВОЇ МІКРОФЛОРИ}

\author{
Тетяна В. Скляр ${ }^{1}$, Катерина В. Лаврентьєва ${ }^{1}$, Олена А. Лихолат ${ }^{1}$, Наталія В. Кондратюк ${ }^{1}$ \\ Катерина Є. Супруненко ${ }^{1}$, Тетяна М. Степанова ${ }^{2}$ \\ ${ }^{1}$ Дніпровський національний університет імені Олеся Гончара, Проспект Гагаріна, 72, Дніпро, 49000, Україна \\ ${ }^{2}$ Сумський національний аграрний університет, вул. Г. Кондратьєва, 160, Суми, 40021, Украӥна
}

\section{Анотація}

У зв'язку зі збільшенням населення світу зростає і необхідність підвищення показників якості продуктів тваринництва і птахівництва. Світовий досвід свідчить про неможливість відмови від використання антибіотиків під час вирощування свиней, BPX, птахів. По перше, це пов'язане із терапевтичними та профілактичними заходами під час боротьби із різними хворобами. По-друге, за рахунок біохімічних перетворень у м'язових волокнах за участю антибіотиків покращуються споживчі (колір, консистенція) та технологічні (вологопоглинаюча та вологоутримуюча здатність) показники якості. Тому продукти тваринництва можуть являтися одним із джерел потрапляння до організму людини санітарно-показової мікрофлори. Метою дослідження став моніторинг розповсюдження антибіотикорезистентних штамів

*Corresponding author: e-mail address: tetiana.stepanova@snau.edu.ua

(C) 2020 Oles Honchar Dnipro National University

doi: 10.15421/082011 
Journal of Chemistry and Technologies, 2020, 28(1), 100-112

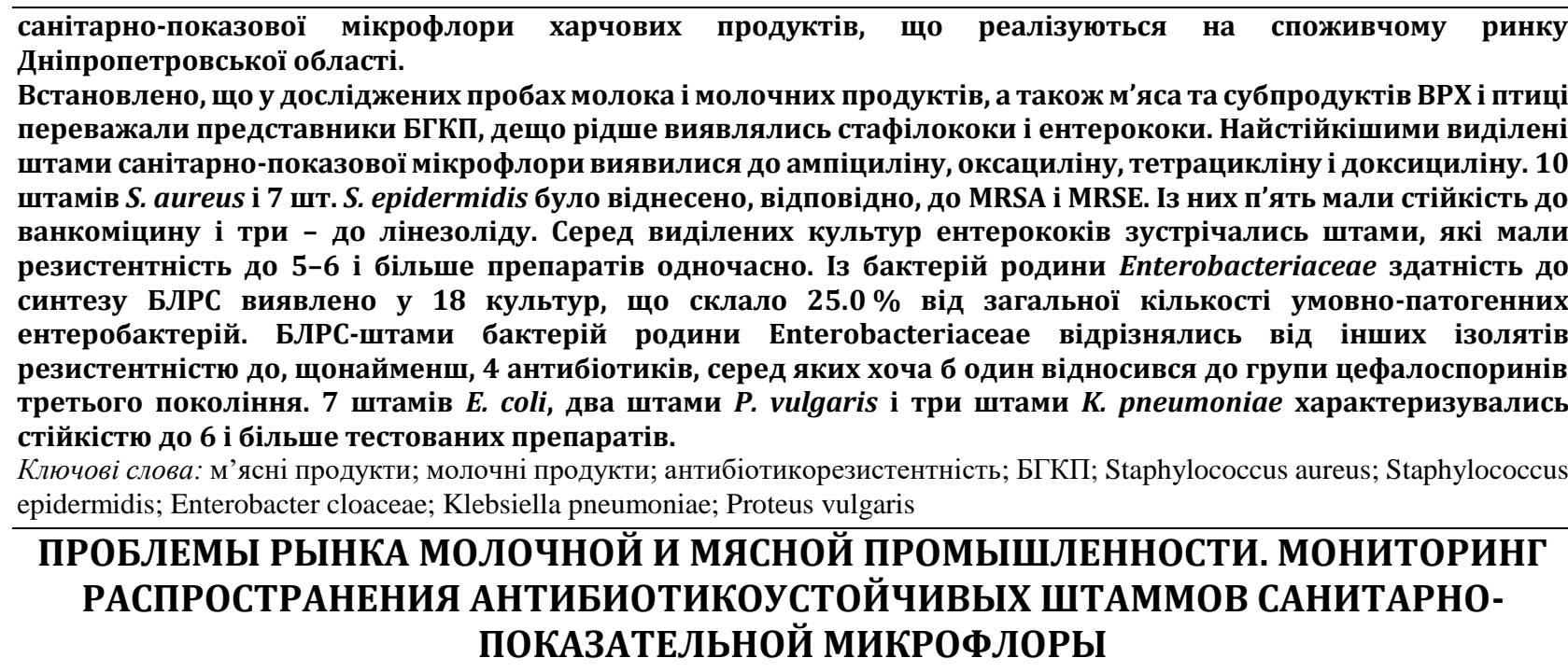

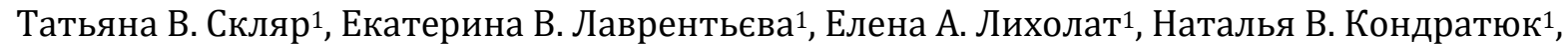
Катерина Е. Супруненко ${ }^{1}$, Татьяна М. Степанова²

${ }_{1}^{1}$ Днипровский национальный университет имени Олеся Гончара, Проспект Гагарина, 72, Днипро, 49000, Украина

${ }^{2}$ Сумской национальный аграрный университет, ул. Г. Кондратьева, 160, Сумы, 40021, Украина

\section{Аннотация}

В связи с увеличением населения Земли растет и необходимость повышения показателей качества продуктов животноводства и птицеводства. Мировой опыт свидетельствует о невозможности отказа от использования антибиотиков в процессе выращивания свиней, КРС, птицы. Во-первых, это связано с терапевтическими и профилактическими мерами во время борьбы с различными болезнями. Во-вторых, за счет биохимических преобразований в мышечных волокнах с участием антибиотиков улучшаются потребительские (цвет, консистенция) и технологические (влагопоглащающая и влагоудерживающая способность) показатели качества. Поэтому продукты животноводства могут являться одним из источников попадания в организм человека санитарно-показательной микрофлоры. Целью исследования стал мониторинг распространения антибиотикорезистентных штаммов санитарно-показательной микрофлоры пищевых продуктов, реализуемых на потребительском рынке Днепропетровской области.

Установлено, что в исследованных пробах молока и молочных продуктов, а также мяса и субпродуктов КРС и птицы преобладали представители БГКП, несколько реже оказывались стафилококки и энтерококки. Устойчивыми выделенные штаммы санитарно-показательной микрофлоры оказались к ампициллину, оксациллину, тетрациклину и доксицилину. 10 штаммов S. aureus и 7 шт. S. epidermidis были отнесены, соответственно, к MRSA и MRSE. Из них пять были устойчивы к ванкомицину и три - к линезолиду. Среди выделенных культур энтерококков встречались штаммы, которые имели резистентность к 5-6 и более препаратам одновременно. Из бактерий семейства Enterobacteriaceae способность к синтезу БЛРС обнаружено у 18 культур, что составило 25.0 \% от общего количества условно-патогенных энтеробактерий. БЛРС-штаммы бактерий семейства En-terobacteriaceae отличались от других изолятов резистентностью к, по меньшей мере, 4 антибиотикам, среди которых хотя бы один относился к группе цефалоспоринов третьего поколения. 7 штаммов E. coli, два штамма P. vulgaris и три штамма K. pпеuтопiae характеризовались устойчивостью к 6 и более тестируемым препаратам.

Ключевые слова: мясные продукты; молочные продукты; антибиотикорезистентность; БГКП, Staphylococcus aureus; Staphylococcus epidermidis; Enterobacter cloaceae; Klebsiella pneumoniae; Proteus vulgaris

\section{Introduction}

Meat and dairy products are the main source of protein in the human nutrition. Therefore, the issue of quality of these product groups always needs attention, both from the Ministry of Health and institutions that control the quality of food raw materials and finished products.

As the population in the world is growing, it is necessary to improve the quality of livestock and poultry products. World experience shows, that it is impossible to abandon the use of antibiotics in the rearing of pigs, cattle and poultry. Firstly, it is related to therapeutic and preventive measures in the fight against various diseases. Secondly, due to biochemical transformations in muscle fibers with the participation of antibiotics, consumer quality indicators (color, consistency) and technological quality indicators (moisture-absorbing and moisture-retaining ability) are improved [1; 8; 32].

The question of the use of antibiotics has its own historiography of events. There is a heated debate around the world between manufacturers, healthcare organizations and environmentalists about the appropriateness of using antibiotics. The influence of the products of their decomposition in the human body is also studied. There is an active search for their substitutes 
among natural plant components. Thus, a group of scientists proved a reduction in the occurrence of salmonella in poultry meat due to the use in the feed of a composition of probiotic microorganisms, in particular lactobacilli with essential oil of thyme [2].

In our opinion, an approach to strengthening the immunity of animals and poultry, such as green tea polyphenols, is very promising [1].

However, it should be borne in mind that some plant components have a limited area of growth, seasonal fluctuations, and, as the most important factor in thinking "to choose or not to choose" high cost. After all, the processing of vegetable raw materials, the production of extracts, essential oils, which have a long shelf life - are costly processes. After all, the processing of vegetable raw materials, the production of extracts, essential oils, which have a long shelf life are very costly.

In recent years, the effects of antibiotics on meat and dairy products on human health have been extensively evaluated [3; 4]. Regarding the obtained research results, it is quite reliable that a number of antibiotics, such as penicillin series, have a detrimental effect on the human body, causing allergic reactions. All antibiotics have the ability to change the background of the intestinal microflora, exposing a person to diseases related to digestion, excretion of metabolic products, reduced immunity. This is unacceptable in the real conditions of society, especially during epidemics and pandemic.

In this regard, it should be noted that the removal of antibiotics from the diet of animals and poultry a few days before slaughter prevents the entry of toxicants into the human body. However, this requires strict quality control in the timeframe provided for the sale of products to the public. Unfortunately, today in most countries, due to the lack of relevant legislation, quality control is entrusted solely to the manufacturer.

There are also technological methods of reducing the content of antibiotics in meat and dairy raw materials, such as thorough washing, heat treatment, proper storage conditions without violating the shelf life. However, they are not able to solve the main problem of antibiotic resistance of opportunistic pathogens strains.

The emergence and spread in the environment of antibiotic-resistant strains of opportunistic pathogens is an urgent problem of medicine, veterinary medicine and animal husbandry not only in Ukraine but also abroad [5 - 7]. Uncontrolled mass and long-term use of drugs with antimicrobial action promotes the formation and accumulation in the body of animals of antibiotic-resistant strains of opportunistic pathogens. They can be released into the environment with excretion products, into the human body through direct contact with animals or through the consumption of animal origin food $[9 ; 10 ; 27]$. Provided that such resistant strains of opportunistic pathogens become the main etiological agent in the occurrence of an infectious process in humans, their elimination from the body will present certain difficulties. In addition, microorganisms can undergo interstitial, intraspecific and intergeneric transmission of antibiotic resistance genes. This will promote the emergence of cultures with acquired antibiotic resistance and the formation of multidrugresistant variants [11].

This explains the ineffectiveness of antibiotic therapy in the treatment of viral and bacterial diseases.

Therefore, the article was paid attention to the monitor the spread of antibiotic-resistant strains of opportunistic pathogens not only among clinical isolates, but also among those isolated from the environment and in foods that are sources of complete proteins.

The aim of the study was to monitor the content of antibiotic-resistant strains of opportunistic bacteria of the genera Staphylococcus, Enterococcus and the family Enterobacteriaceae in food products sold in consumer markets of Dnipropetrovsk region.

\section{Results and discussion}

Samples of food products were used as objects of research: meat and by-products of cattle and poultry, milk and sour-milk products (cheese, sour cream, kefir). Sampling of meat and dairy products was carried out at the trade markets of Dnipro. Samples for analysis were prepared according to DSTU ISO 6887-1:2003. Sanitary and microbiological examination of milk and dairy products was performed according to GOST 922584 and GOST 30347-2016, meat and meat products was performed according to GOST R 54354-2011 [12-14].

The species affiliation of the isolated strains of enterobacteria was determined using the test "API 20E" ("BioMerieux", France), enterococci - by "API 20 STREP" ("BioMerieux", France), staphylococci by "API Staph" ("BioMerieux", France).

With used Disco-diffusion method and the method of minimal serial dilutions (ISO 207761.2006) in selected cultures of opportunistic bacteria determined the degree of sensitivity to a number of antibiotics of different pharmacological groups. Standard discs with antibiotics were used 
Journal of Chemistry and Technologies, 2020, 28(1), 100-112

during the disco-diffusion method. The set of antibiotics included ampicillin, oxacillin, imipenem, cefotaxime, ceftriaxone, amoxicillin/clavulanic acid, ceftazidime, ciprofloxacin, levofloxacin, amikacin, gentamicin, vancomycin, tetracycline, doxycycline, chloramphenicol, linezolid, erythromycin, azithromycin, nitrofurantoin. Sensitivity assessment of isolated bacterial strains was performed according to CLSI/NCCLS criteria. The sensitivity of experimental cultures of microorganisms was assessed by the SIR system, according to which test objects were divided into the following categories: sensitive (S-sensitive), moderately resistant (MR), resistant (Rresistance) [30].

Due to the fact that special dangers to human and animal health due to the presence of multiple antibiotic resistance are strains of the family Enterobacteriaceae, capable of producing BLES ( $\beta$-lactamase extended spectrum), and oxacillinresistant strains of staphylococci, some interest was in research from the isolation of food isolates of these microorganisms. Strains of enterobacteria capable of synthesizing BLES were detected by the double-disc method. This method is a variant of the classical disco-diffusion method for determining the sensitivity to antibiotics and allows to detect the production of ESBL in the presence of an extended zone of growth retardation around the disk with cephalosporins in front of the disk with clavulanic acid. Disks with amoxicillin/clavulanate $(20 / 10 \mathrm{mcg})$, cefotaxime

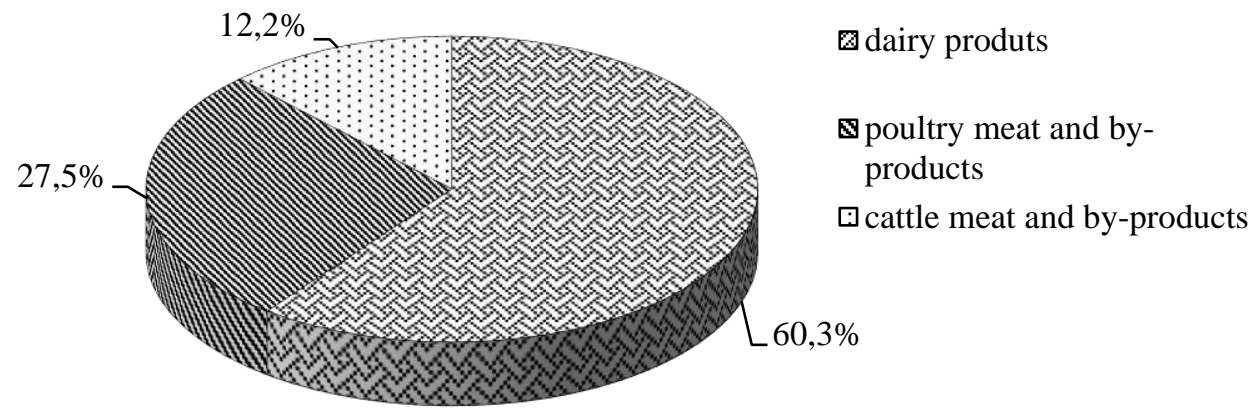

Fig. 1. Frequency of food samples detection that do not meet regulatory indicators

It should be noted, the titer of bacteria of the genus Staphylococcus (average for all samples with deviations) in dairy products was the highest. The likelihood of this fact is that milk and dairy products have been contaminated with microflora from the skin and mucous membranes of animals and workers during production and sale. There is a high level of their content in dairy products due to the fact, that staphylococci show lipase and proteolytic activity and have the ability to utilize lactose. This causes toxicoinfection. Our results
(30 mcg), ceftriaxone (30 mcg) and ceftazidime (30 mcg) were used to set up the method. The presence of an extended zone of growth retardation around at least one of the tested cephalosporins allows to attribute the experimental strain to the producers of ESBL [16].

Given that in staphylococcal strains multiple antibiotic resistance occurs mainly in isolates resistant to oxacillin due to the production of penicillin-binding protein 2a (PBP 2a), they were detected by inoculation on meat-peptone agar with methicillin (oxacillin) simultaneously [17]. Staphylococcal and enterobacterial cultures from the international collection were used as controls.

\section{Experimental part}

548 of food samples were analyzed. Among them, $229(41.8 \%)$ did not meet regulatory standards. 138 of them $(60.3 \%)$ were dairy products, $63(27.5 \%)$ were poultry meat and byproducts, $28(12.2 \%)$ were meat and cattle byproducts (Fig. 1). Samples of dairy products that did not meet microbiological standards were characterized by the presence of sanitaryindicative microflora: bacteria of the Escherichia coli group were detected in $24.6 \%$ of samples, bacteria Staphylococcus - $18.8 \%$, Enterococcus $5.8 \%$ of samples (Table 1). Their titers (average value for samples with deviations from the norm) were $2.95 \pm 0.42$, respectively; $3.88 \pm 0.79$ and $2.78 \pm 0.83 \mathrm{lg} \mathrm{CFU} / \mathrm{g}$ of product. confirm the observations of Goryuk Yu. V. [6]. He showed, that Staphylococcus aureus of two biotypes S. aureus var. bovis and S. aureus var. hominis is most often isolated from raw milk and home-made dairy products. The author describes the ways of getting them into food: from the skin and mammary glands of animals during milking, as well as from the skin of the hands and mucous membranes of workers and sellers. This indicates a low level of compliance with hygiene and sanitary requirements during the production of 
Journal of Chemistry and Technologies, 2020, 28(1), 100-112

milk and dairy products. It is necessary to pay attention to this to producers and regulatory authorities of the state regulation of food quality issues.
Indicators of contamination of the sanitary and indicative microflora of meat and dairy products, which were sold at points of sale in the markets of the Dnipropetrovsk region are shown in Table 1.

Indicators of contamination of dairy and meat products of sanitary-oriented microflora

\begin{tabular}{|c|c|c|c|c|c|c|c|c|c|c|}
\hline \multirow{3}{*}{ 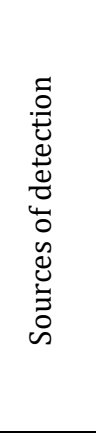 } & \multirow{3}{*}{ 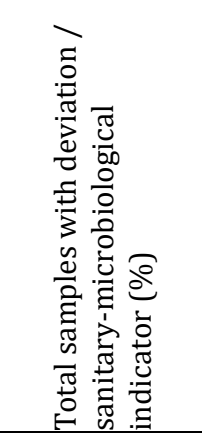 } & \multicolumn{9}{|c|}{ Sanitary and microbiological indicator } \\
\hline & & \multicolumn{3}{|c|}{$\begin{array}{l}\text { bacterium of intestinal } \\
\text { bacillus }\end{array}$} & \multicolumn{3}{|c|}{ p. Staphylococcus } & \multicolumn{3}{|c|}{ p. Enterococcus } \\
\hline & & Abs.n. & $\%$ & $\lg \mathrm{CFU} / \mathrm{g}^{*}$ & Abs.n & $\%$ & $\lg \mathrm{CFU} / \mathrm{g}^{*}$ & Abs.n. & $\%$ & $\lg \mathrm{CFU} / \mathrm{g}^{*}$ \\
\hline 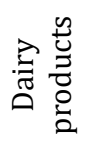 & $\begin{array}{c}138 / \\
68(49.2)\end{array}$ & 34 & 24.6 & $2.95 \pm 0.42$ & 26 & 18.8 & $3.88 \pm 0.79$ & 8 & 5.8 & $2.78 \pm 0.83$ \\
\hline 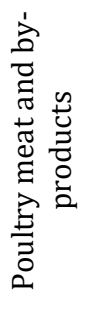 & $63 / 56(88.9)$ & 28 & 44.4 & $4.26 \pm 0.63$ & 19 & 30.2 & $2.86 \pm 0.42$ & 9 & 14.3 & $3.50 \pm 0.83$ \\
\hline 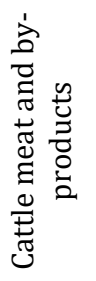 & $28 / 23(82.1)$ & 10 & 35.7 & $3.73 \pm 1.97$ & 9 & 32.1 & $2.41 \pm 0.64$ & 4 & 14.3 & $2.66 \pm 1.73$ \\
\hline
\end{tabular}

Note: * average of samples with deviations from the norm

Bacterium of intestinal bacillus $(41.7 \%$ of cases), staphylococci (30.8\%), and enterococci $(14.3 \%)$ were also the most common in meat products. Titers (average) of Bacterium of intestinal bacillus, bacteria of the genera Staphylococcus and Enterococcus in samples of poultry meat and by-poducts with deviations from the normative indicators were $4.26 \pm 0.63$, respectively; $2.86 \pm 0.42$ and $3.50 \pm 0.83 \mathrm{CFU} / \mathrm{g}$ of product, and in samples of meat and cattle byproducts $-3.73 \pm 1.97,2.41 \pm 0.64$ and $2.66 \pm 1.73$ $\mathrm{CFU} / \mathrm{g}$ of product. As can be seen from the data obtained, samples of poultry meat and byproducts were characterized by the highest degree of contamination with sanitary-indicative microflora, primarily members of the family Enterobacteriaceae. Similar results are presented in the work of Korotkevich Yu. V., where it was shown that the highest level of enterobacterial contamination was registered in samples of milk, poultry meat and poultry by-products [11].

The most diverse species composition of Bacterium of intestinal bacillus was found in samples of milk and dairy products (Fig. 2). 

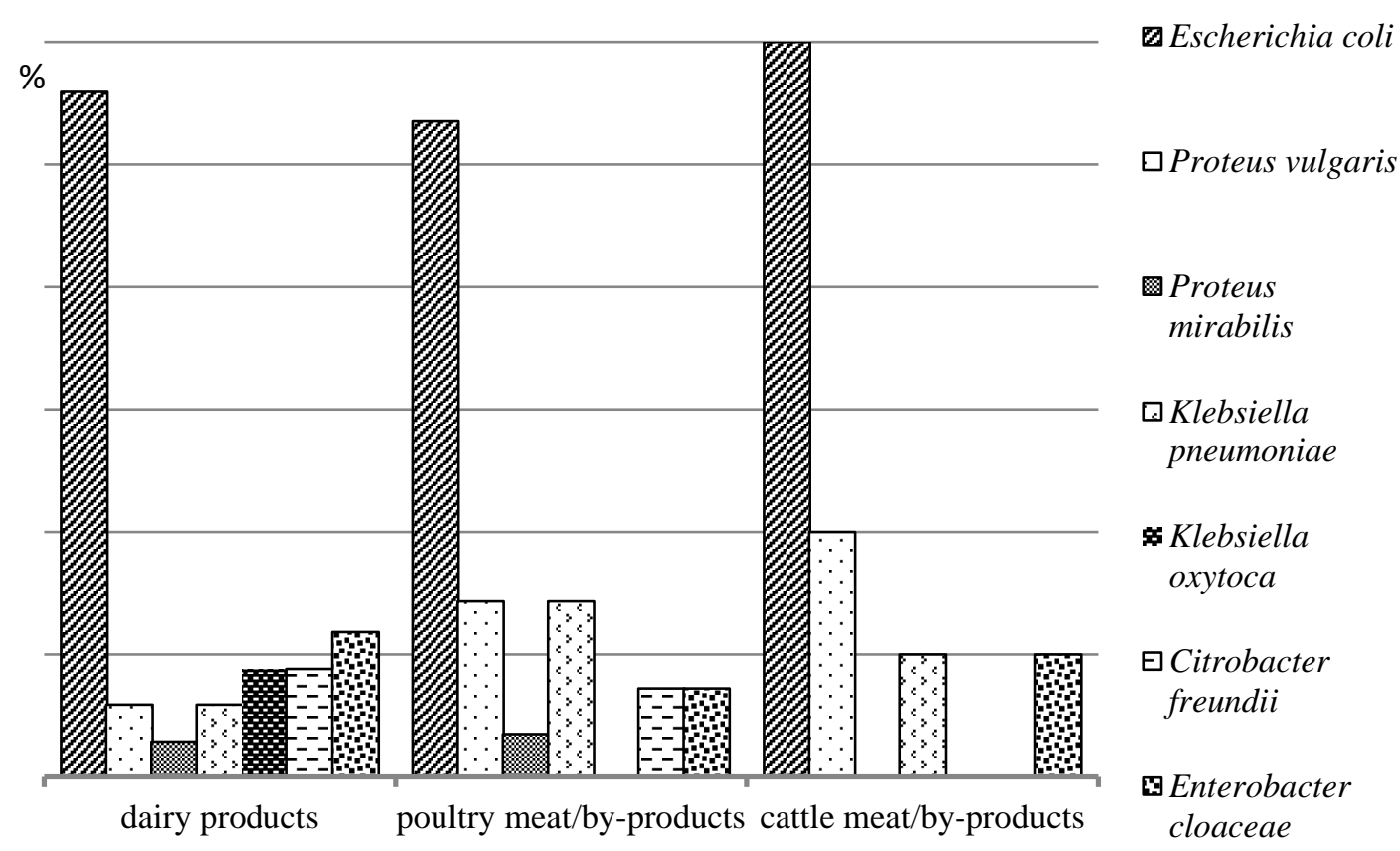

Fig. 2. Species composition of bacterium of intestinal bacillus in samples of dairy and meat products

Escherichia coli predominated among all isolated species of enterobacteria. Thus, Escherichia coli was isolated from samples of dairy products in $55.9 \%$ of cases, from samples of poultry meat and by-products in $53.5 \%$ as well as from meat and cattle by-products in $60.0 \%$ of cases. Slightly less often Enterobacter cloaceae was sown from dairy samples in $11.8 \%$ of cases, from beef samples $P$. vulgaris in $20.0 \%$ of cases, from poultry samples $P$. vulgaris and Klebsiella pneumoniae with the same frequency in $14.3 \%$ of cases. Other bacterial species were detected in isolated cases, the frequency of their seeding from the samples did not exceed $10 \%$.

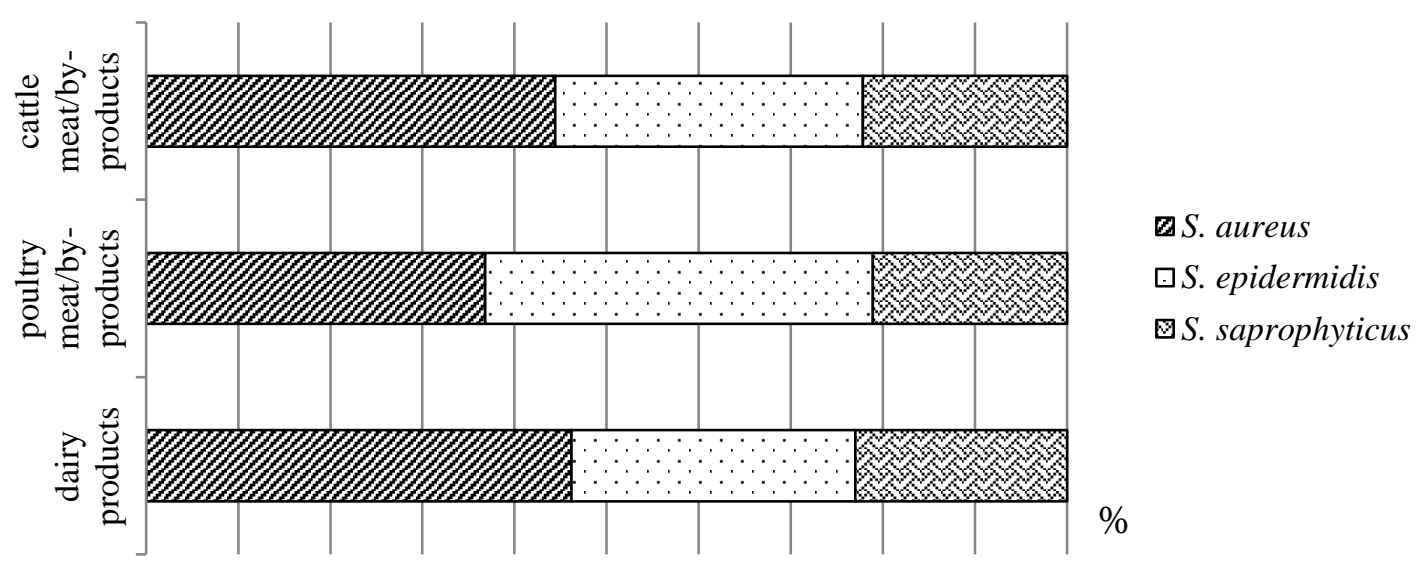

Fig. 3 Species composition and quantitative ratio of staphylococcal strains isolated from food products

The species composition of staphylococci isolated from experimental samples with deviations was represented by Staphylococcus aureus, epidermal and saprophytic staphylococci (Fig. 3). Among them, Staphylococcus aureus strains were the most common in milk, meat and cattle by-products, in $46.2 \%$ and $44.4 \%$, respectively. Staphylococcus $S$. epidermidis predominated in poultry meat and by-products samples. The frequency of their selection in the experimental samples was $42.1 \%$. $S$. saprophyticus strains were found in the smallest amount (not more than $23.0 \%$ ) in food samples.

Among the coccal microflora, in addition to staphylococci, enterococci Enterococcus faecium and E. faecalis were isolated from the experimental samples. They were most often isolated from samples of poultry meat, poultry byproducts and dairy products. Thus, strains of $E$. faecium were sown from samples of meat and poultry offal in $66.7 \%$, and E. faecalis - in $33.3 \%$ of cases (six and three contaminated samples), 
from dairy products - respectively in $37.5 \%$ and $62.5 \%$ of cases ( 3 and 5 contaminated samples). Only two samples had E. faecium and two had $E$. faecalis for meat and cattle by-products.

At the next stage, the level of sensitivity to antibiotics of different pharmacological groups, which are most widely used in modern medical and veterinary practice, was determined in the selected strains of opportunistic bacteria.

The results of the analysis of staphylococci antibiotic susceptibility are presented in the Table 2.

Staphylococcal strains were the most resistant to penicillin antibiotics ampicillin and oxacillin (79.6 and $68.5 \%$ of cultures, respectively). In addition, a high level of resistance was observed in these strains to macrolides and tetracyclines. Resistance to erythromycin was found in $61.1 \%$ of staphylococcal strains, to doxycillin $-59.3 \%$, to azithromycin and tetracycline - $51.9 \%$ of the studied isolates. In terms of species, the largest number of resistant to these antibiotics strains of staphylococci were registered among $S$. aureus and $S$. epidermidis. Among the total number of strains to ampicillin were resistant $37.0 \%$ and $31.5 \%$ of isolates of Staphylococcus aureus and Staphylococcus epidermidis, to oxacillin - $33.3 \%$ and $27.8 \%$ of cultures, respectively. 10 strains of $S$. aureus and 7 strains of $S$. epidermidis were resistant to oxacillin. They were assigned to the group of methicillin-resistant cultures - MRSA and MRSE.

The resistance of the above-described staphylococcal strains to modern $\beta$-lactam antibiotics, in particular to imipenem (1 strain), cefotaxime (5 cultures), ceftriaxone (7 isolates), ceftazidime (7 strains), amoxicillin/clavulanic acid (7), became important. Our results are consistent with the results of other researchers. They found that MRSA is characterized by a high level of resistance to antibiotics of various pharmacological groups, namely macrolides, aminoglycosides, fluoroquinolones, and especially to the group of $\beta$-lactams, including penicillins and cephalosporins of all generations $[18 ; 19 ; 31]$.

In addition, of the staphylococcal isolates we isolated, five were resistant to vancomycin and three to linezolid, the drugs of choice for the treatment of infections caused by strains of methicillin-resistant staphylococci with multiple antibiotic resistances $[20 ; 21]$. The data suggest that the presence of such isolates in the body of sick people, significantly complicates the treatment of infections caused by staphylococci, described in this paper. This creates limitations and explains the ineffectiveness of using a wide range of antibiotics in a large number of clinical cases. In modern medical and veterinary practice, this problem is becoming increasingly important and alarming in the field of health care [22; 23].

Enterococcal strains were characterized by an even higher level of antibiotic resistance compared to staphylococci(Tabl. 3). More than $50.0 \%$ of isolates of the genus Enterococcus were resistant to $\beta$-lactams: ampicillin, oxacillin, amoxiclav, cefotaxime, ceftriaxone, ceftazidime, as well as ciprofloxacin, gentamicin, nitrofurantoin, tetracycline, doxycycline and vancomycin.

Among this range of antibiotics, ampicillin, ceftriaxone, ciprofloxacin, tetracycline and doxycycline were the least effective against the selected enterococcal strains. Only $33.3 \%$ of all tested isolates of the genus Enterococcus were sensitive to them.

It should be noted that among the isolated cultures of enterococci there were strains that had resistance to 5-6 or more drugs simultaneously. This allows them to be classified as multiresistant [24].

Similar results are described in the articles of the authors Minaeva L.P. [25] and Korotkevich Yu. V. [11]. They showed that $40-70 \%$ of enterococci were resistant to tetracycline.

The fact that meat and dairy products are the most common strains of opportunistic bacteria resistant to penicillins and tetracyclines is due to the fact that these antibiotics are most often used in animal husbandry to stimulate animal growth and treat infectious diseases. As a result, they are most often found in food products of animal origin in quantities exceeding the norms of standards and sanitary rules and regulations [26; 27].

The highest percentage of strains resistant to penicillin was registered among members of the Enterobacteriaceae. Resistance to ampicillin was found in $86.1 \%$ of enterobacterial isolates, to oxacillin in $84.7 \%$, to amoxicillin / clavulanate in $75.0 \%$. $60.0 \%$ of cultures were resistant to nitrofurantoin, $66.7 \%$ and $72.2 \%$ to tetracycline and doxycycline. The largest number of insensitive strains was found among isolates of the genus Proteus and Klebsiella. 
Journal of Chemistry and Technologies, 2020, 28(1), 100-112

Table 2

Sensitivity to antibiotics of Staphylococcus strains isolated from food

\begin{tabular}{|c|c|c|c|c|c|c|c|c|c|c|c|c|}
\hline \multirow[t]{2}{*}{ Antibiotics } & \multicolumn{3}{|c|}{$\begin{array}{l}\text { S. aureus, abs.n./\% } \\
\qquad(\mathrm{n}=23)\end{array}$} & \multicolumn{3}{|c|}{$\begin{array}{l}\text { S. epidermidis, } \\
\text { abs.n./\% }(\mathrm{n}=19)\end{array}$} & \multicolumn{3}{|c|}{$\begin{array}{l}\text { S. saprophyticus, } \\
\text { abs.n./\% }(\mathrm{n}=12)\end{array}$} & \multicolumn{3}{|c|}{$\begin{array}{c}\text { For all types of } \\
\text { staphylococci, abs.n./\% } \\
(\mathrm{n}=54)\end{array}$} \\
\hline & $S$ & $\mathrm{R}$ & IR & $S$ & $\mathrm{R}$ & IR & $S$ & $\mathrm{R}$ & IR & $S$ & $\mathrm{R}$ & IR \\
\hline $\mathrm{Am}$ & $3 / 13.0$ & $3 / 56.6$ & $7 / 30.4$ & $2 / 10.5$ & $11 / 57.9$ & $6 / 31.6$ & $6 / 50.0$ & $2 / 16.7$ & $4 / 33.3$ & $11 / 20.4$ & $26 / 48.1$ & $17 / 31.5$ \\
\hline Or & 21.7 & $0 / 43.6$ & $8 / 34.7$ & $4 / 21.0$ & $7 / 36.8$ & $8 / 42.1$ & $8 / 66.7$ & $1 / 8.3$ & $3 / 25.0$ & $17 / 31.5$ & $18 / 33.3$ & $19 / 35.2$ \\
\hline Imip & $/ 87.0$ & $1 / 4.3$ & $2 / 8.7$ & $17 / 89.5$ & $0 / 0$ & $2 / 10.5$ & $11 / 91.7$ & $0 / 0$ & $1 / 8.3$ & $48 / 88.8$ & $1 / 1.9$ & $5 / 9.3$ \\
\hline Cefo & $/ 74.0$ & $3 / 13.0$ & $3 / 13.0$ & $12 / 63.2$ & $2 / 10.5$ & $5 / 26.3$ & $8 / 66.7$ & $0 / 0$ & $4 / 33.3$ & $37 / 68.5$ & $5 / 9.3$ & $12 / 22.2$ \\
\hline Cef & 169.6 & $4 / 17.4$ & $3 / 13.0$ & $14 / 73.7$ & $2 / 10.5$ & $3 / 15.8$ & $9 / 75.0$ & $1 / 8.3$ & $2 / 16.7$ & $39 / 72.2$ & $7 / 13.0$ & $8 / 14.8$ \\
\hline Ceftc & $/ 78.3$ & $3 / 13.0$ & $2 / 8.7$ & $13 / 68.4$ & $3 / 15.8$ & $3 / 15.8$ & $10 / 83.4$ & $1 / 8.3$ & $1 / 8.3$ & $41 / 75.9$ & 7/13.0 & $6 / 11.1$ \\
\hline $\begin{array}{l}\text { illin / } \\
\text { ic acid }\end{array}$ & $15 / 65.2$ & $4 / 17.4$ & $4 / 17.4$ & $12 / 63.2$ & $2 / 10.5$ & $5 / 26.3$ & $9 / 75.0$ & $1 / 8.3$ & 2/16.7 & $36 / 66.6$ & 7/13.0 & $11 / 20.4$ \\
\hline Ciprof & 8.3 & $2 / 8.7$ & $3 / 13.0$ & 0.0 & $2 / 10.5$ & $2 / 10.5$ & $8 / 66.7$ & $0 / 0$ & $4 / 33.3$ & $41 / 75.9$ & $4 / 7.4$ & $9 / 16.7$ \\
\hline Levol & $19 / 82.6$ & $1 / 4.3$ & $3 / 13.0$ & $17 / 89.4$ & $1 / 5.3$ & $1 / 5.3$ & $11 / 91.7$ & $0 / 0$ & $1 / 8.3$ & $47 / 87.0$ & $2 / 3.7$ & $5 / 9.3$ \\
\hline $\mathrm{n}$ & .47 .9 & $5 / 21.7$ & $7 / 30.4$ & $14 / 73.7$ & $3 / 15.8$ & $2 / 10.5$ & $8 / 66.7$ & $2 / 16.7$ & $2 / 16.7$ & $33 / 61.1$ & $10 / 18.5$ & $11 / 20.4$ \\
\hline & $/ 52.3$ & $5 / 21.7$ & $6 / 26.0$ & $14 / 73.7$ & $3 / 15.8$ & $2 / 10.5$ & $7 / 58.3$ & $2 / 16.7$ & $3 / 25.0$ & $33 / 61.1$ & $10 / 18.5$ & $11 / 20.4$ \\
\hline Van & 78.3 & $3 / 13.0$ & $2 / 8.7$ & $16 / 84.2$ & $2 / 10.5$ & $1 / 5.3$ & $10 / 83.3$ & $0 / 0$ & $2 / 16.7$ & $44 / 81.4$ & $5 / 9.3$ & $5 / 9.3$ \\
\hline line & $10 / 43.6$ & $7 / 30.4$ & $6 / 26.0$ & $10 / 52.6$ & $6 / 31.6$ & $3 / 15.8$ & $6 / 50.0$ & $3 / 25.0$ & $3 / 25.0$ & $26 / 48.1$ & $16 / 29.7$ & $12 / 22.2$ \\
\hline Doxy & $/ 39.3$ & $8 / 34.7$ & $6 / 26.0$ & $8 / 42.1$ & $6 / 31.6$ & $5 / 26.3$ & $5 / 41.7$ & $3 / 25.0$ & $4 / 33.3$ & $22 / 40.7$ & $17 / 31.5$ & $15 / 27.8$ \\
\hline $\begin{array}{l}\text { Chloramphenic } \\
\text { ol }\end{array}$ & 5.3 & 3.0 & 5 & 7.9 & .5 & 1.6 & 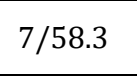 & 3 & .3 & 3 & 6/11.1 & 8 \\
\hline Linezolid & $19 / 82.6$ & $2 / 8.7$ & $2 / 8.7$ & $16 / 84.2$ & $1 / 5.3$ & $2 / 10.5$ & $12 / 100.0$ & $0 / 0$ & $0 / 0$ & $47 / 87.0$ & $3 / 5.6$ & $4 / 7.4$ \\
\hline Nitroft & $9 / 39.2$ & $7 / 30.4$ & $7 / 30.4$ & $10 / 52.6$ & $4 / 21.1$ & $5 / 26.3$ & $9 / 75.0$ & $1 / 8.3$ & $2 / 16.7$ & $28 / 51.9$ & $12 / 22.2$ & $14 / 25.9$ \\
\hline & $8 / 34.7$ & $9 / 39.3$ & $6 / 26.0$ & $7 / 36.8$ & $7 / 36.8$ & $5 / 26.3$ & $6 / 50.0$ & $2 / 16.7$ & 4/33.3 & $21 / 38.9$ & $18 / 33.3$ & $15 / 27.8$ \\
\hline Azithromycin & $10 / 43.6$ & $7 / 30.4$ & $6 / 26.0$ & $8 / 42.1$ & $5 / 26.3$ & $6 / 31.6$ & $8 / 66.7$ & $1 / 8.3$ & $3 / 25.0$ & $26 / 48.1$ & $13 / 24.1$ & $15 / 27.8$ \\
\hline
\end{tabular}

Antibiotic sensitivity of enterococcal strains isolated from food

Table 3

\begin{tabular}{|c|c|c|c|c|c|c|c|c|c|}
\hline \multirow[t]{2}{*}{ Antibiotics } & \multicolumn{3}{|c|}{ E. faecium, abs.n./\% (n=11) } & \multicolumn{3}{|c|}{ E. faecalis, abs.n./\% $(\mathrm{n}=10)$} & \multicolumn{3}{|c|}{$\begin{array}{c}\text { For all types of enterococci, } \\
\text { abs.n./\% (n=21) }\end{array}$} \\
\hline & $\mathrm{S}$ & $\mathrm{R}$ & IR & $\mathrm{S}$ & $\mathrm{R}$ & IR & $\mathrm{S}$ & $\mathrm{R}$ & IR \\
\hline Ampicillin & $4 / 36.3$ & $4 / 36.3$ & $3 / 27.4$ & $3 / 30.0$ & $6 / 60.0$ & $1 / 10.0$ & $7 / 33.3$ & $10 / 47.7$ & $4 / 19.0$ \\
\hline Oxacillin & $5 / 45.5$ & $2 / 18.2$ & $4 / 36.3$ & $3 / 30.0$ & $5 / 50.0$ & $2 / 20.0$ & $8 / 38.1$ & $7 / 33.3$ & $6 / 28.6$ \\
\hline Amoxiclav & $6 / 54.4$ & $3 / 27.4$ & $2 / 18.2$ & $3 / 30.0$ & $6 / 60.0$ & $1 / 10.0$ & $9 / 42.9$ & $9 / 42.9$ & $3 / 14.2$ \\
\hline Imipenem & $9 / 81.8$ & $0 / 0.0$ & $2 / 18.2$ & $9 / 90.0$ & $0 / 0.0$ & $1 / 10.0$ & $18 / 85.8$ & $0 / 0$ & $3 / 14.2$ \\
\hline Cefotaxime & $5 / 45.5$ & $4 / 36.3$ & $2 / 18.2$ & $4 / 40.0$ & $4 / 40.0$ & $2 / 20.0$ & $9 / 42.9$ & $8 / 38.1$ & $4 / 19.0$ \\
\hline Ceftriaxone & $3 / 27.3$ & $5 / 45.5$ & $3 / 27.3$ & $4 / 40.0$ & $3 / 30.0$ & $3 / 30.0$ & $7 / 33.3$ & $8 / 38.1$ & $6 / 28.6$ \\
\hline Ceftazidime & $5 / 45.5$ & $4 / 36.3$ & $2 / 18.2$ & $5 / 50.0$ & $3 / 30.0$ & $2 / 20.0$ & $10 / 47.7$ & $7 / 33.3$ & $4 / 19.0$ \\
\hline Ciprofloxacin & $3 / 27.4$ & $6 / 54.4$ & $2 / 18.2$ & $4 / 40.0$ & $5 / 50.0$ & $1 / 10.0$ & $7 / 33.3$ & $11 / 52.4$ & $3 / 14.3$ \\
\hline Levofloxacin & $7 / 63.6$ & $1 / 9.0$ & $3 / 27.4$ & $8 / 80.0$ & $1 / 10.0$ & $1 / 10.0$ & $15 / 71.5$ & $2 / 9.5$ & $4 / 19.0$ \\
\hline Amikacin & $6 / 54.4$ & $2 / 18.2$ & $3 / 27.4$ & $5 / 50.0$ & $3 / 30.0$ & $2 / 20.0$ & $11 / 52.4$ & $5 / 23.8$ & $5 / 23.8$ \\
\hline Gentamicin & $5 / 45.5$ & $2 / 18.2$ & $4 / 36.3$ & $4 / 40.0$ & $3 / 30.0$ & $3 / 30.0$ & $9 / 42.9$ & $5 / 23.8$ & $7 / 33.3$ \\
\hline Tetracycline & $3 / 27.4$ & $6 / 54.4$ & $2 / 18.2$ & $4 / 40.0$ & $3 / 30.0$ & $3 / 30.0$ & $7 / 33.3$ & $9 / 42.9$ & $5 / 23.8$ \\
\hline Doxycilline & $2 / 18.2$ & $7 / 63.6$ & $2 / 18.2$ & $5 / 50.0$ & $2 / 20.0$ & $3 / 30.0$ & $7 / 33.3$ & $9 / 42.9$ & $5 / 23.8$ \\
\hline Chloramphenicol & $7 / 63.6$ & $2 / 18.2$ & $2 / 18.2$ & $6 / 60.0$ & $2 / 20.0$ & $2 / 20.0$ & $13 / 62.0$ & $4 / 19.0$ & $4 / 19.0$ \\
\hline Nitrofurantoin & $5 / 45.5$ & $3 / 27.3$ & $3 / 27.3$ & $4 / 40.0$ & $3 / 30.0$ & $3 / 30.0$ & $9 / 42.9$ & $6 / 28.6$ & $6 / 28.6$ \\
\hline Vancomycin & $5 / 45.5$ & $1 / 9.0$ & $5 / 45.5$ & $4 / 40.0$ & $3 / 30.0$ & $3 / 30.0$ & $9 / 42.9$ & $4 / 19.0$ & $8 / 38.1$ \\
\hline
\end{tabular}

Note: $\mathrm{S}$ - sensitive; R - resistant; IR - moderately resistant 
Sensitivity to antibiotics of strains of the family Enterobacteriaceae isolated from food

\begin{tabular}{|c|c|c|c|c|c|c|c|c|c|c|c|c|c|c|c|c|c|c|}
\hline \multirow[t]{2}{*}{ Antibio- } & \multicolumn{3}{|c|}{$\begin{array}{l}\text { E. coli, abs.n./\% } \\
(\mathrm{n}=40)\end{array}$} & \multicolumn{3}{|c|}{$\begin{array}{c}\text { Proteus spp., } \\
\text { abs.n./\% }(\mathrm{n}=10)\end{array}$} & \multicolumn{3}{|c|}{$\begin{array}{c}\text { Klebsiella spp. } \\
\text { abs.n./\% }(\mathrm{n}=10)\end{array}$} & \multicolumn{3}{|c|}{$\begin{array}{c}\text { Citrobacter } \\
\text { freundii, } \\
\text { abs.n./\% }(\mathrm{n}=5)\end{array}$} & \multicolumn{3}{|c|}{$\begin{array}{c}\text { Enterobacter } \\
\quad \text { cloaceae } \\
\text { abs.n./\% }(\mathrm{n}=7) \\
\end{array}$} & \multicolumn{3}{|c|}{$\begin{array}{l}\text { For all types of } \\
\text { enterobacteria, } \\
\text { abs.n./\% }(n=72)\end{array}$} \\
\hline & S & N & IR & $S$ & $\pi$ & & 5 & $D$ & & $S$ & $\mathrm{R}$ & & $\Omega_{1}$ & $\mathrm{R}$ & & $C_{1}$ & 工 & (3) \\
\hline & $\begin{array}{c}6 / \\
15.0 \\
\end{array}$ & 7 & & $1 /$ & & J & 2 & $\begin{array}{c}7 / \\
70.0\end{array}$ & & 0 & $\begin{array}{l}4 / \\
30.0 \\
\end{array}$ & 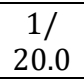 & 3 & 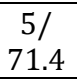 & & & & \\
\hline & $\begin{array}{c}7 / \\
17.5 \\
\end{array}$ & & 7/ & $\begin{array}{c}1 / \\
10.0 \\
\end{array}$ & 7 & 20.0 & $\begin{array}{c}1 / \\
10.0 \\
\end{array}$ & & 1/ & 20.0 & $\begin{array}{c}3 / \\
60.0 \\
\end{array}$ & $\begin{array}{l}1 / \\
20.0 \\
\end{array}$ & $\begin{array}{l}1 / \\
4.3 \\
\end{array}$ & $4 /$ & 2 & 1 & & $3 /$ \\
\hline & 2 & & 8/ & $3 /$ & & $2 /$ & $2 /$ & & $2 /$ & 1/ & $\begin{array}{l}3 / \\
60.0\end{array}$ & 0 & $2 / 2$ & $\begin{array}{l}3 / \\
42.8\end{array}$ & $2 /$ & & & 0.8 \\
\hline & $\begin{array}{l}38 / \\
95.0 \\
\end{array}$ & & & & & .0 & & & & $4 /$ & & & & & & & & \\
\hline & $\begin{array}{l}30 / \\
75.0 \\
\end{array}$ & $\begin{array}{c}6 / \\
15.0\end{array}$ & 4 & $\begin{array}{l}6 / \\
60.0\end{array}$ & $2 /$ & 20 & $\begin{array}{l}7 / \\
70.0\end{array}$ & 21 & $\begin{array}{l}1 / \\
10.0\end{array}$ & $\begin{array}{l}3 / \\
60.0\end{array}$ & $\begin{array}{l}1 / \\
20.0\end{array}$ & $\begin{array}{c}1 / \\
20.0\end{array}$ & $\begin{array}{c}5 / \\
71.4\end{array}$ & $\begin{array}{l}1 / \\
14.3\end{array}$ & 1 & & & $\begin{array}{l}9 / \\
2.5\end{array}$ \\
\hline & $\begin{array}{l}31 / \\
77.5 \\
\end{array}$ & 12.5 & 4 & $7 /$ & 1 & 20.0 & 81 & $1 /$ & 11 & $\begin{array}{l}4 / \\
30.0\end{array}$ & $\begin{array}{l}0 / \\
0.0\end{array}$ & 20.0 & $\begin{array}{l}6 / \\
85.7\end{array}$ & $1 /$ & 0 & & & $\begin{array}{l}8 / \\
1.1 \\
\end{array}$ \\
\hline & 80.0 & & & & & & & & & & $1 /$ & & & & & & & \\
\hline & $\begin{array}{l}33 / \\
82.5 \\
\end{array}$ & 1 & $4 /$ & $8 /$ & $1 /$ & $1 /$ & $\begin{array}{c}7 / \\
70.0\end{array}$ & 20.0 & $\begin{array}{l}1 / \\
10.0\end{array}$ & $\begin{array}{c}3 / \\
60.0 \\
\end{array}$ & $\begin{array}{l}0 / \\
0.0\end{array}$ & $\begin{array}{c}2 / \\
40.0\end{array}$ & $\begin{array}{c}5 / \\
71.4\end{array}$ & $0 /$ & 21 & $y$ & & $\begin{array}{l}0 / \\
3.9\end{array}$ \\
\hline & $\begin{array}{l}36 / \\
90.0 \\
\end{array}$ & 2.5 & & .0 & 0 & 20 & 80.0 & . & .0 & 00.0 & 0.0 & 20.0 & 85.7 & 0.0 & & & & 2.5 \\
\hline & & & 4121 & 60 & 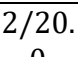 & 120 & 150 & 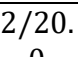 & 20 & 180 & $0 / 0$ & 120 & $150^{\circ}$ & 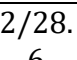 & & & & 12 \\
\hline & .0 & & & & & & & & & & & & & & & & & 7 \\
\hline & $\begin{array}{l}22 / \\
55.0\end{array}$ & & 10 & 5 & $2 /$ & 3 & 0 & 20.0 & $\begin{array}{l}3 / \\
30.0\end{array}$ & $\begin{array}{l}3 / \\
60.0\end{array}$ & $\begin{array}{c}1 / \\
20.0\end{array}$ & 20.0 & $\begin{array}{l}3 / \\
+2.8\end{array}$ & 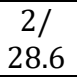 & $2 /$ & & & $\begin{array}{l}9 / \\
6.4\end{array}$ \\
\hline & 15 & & & 2 & $\begin{array}{c}7 / \\
70.0\end{array}$ & $1 /$ & 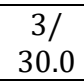 & 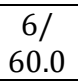 & 1 & $2 /$ & $\begin{array}{c}2 / \\
40.0\end{array}$ & $\begin{array}{c}1 / \\
20.0\end{array}$ & 28.6 & $\begin{array}{c}3 / \\
42.8\end{array}$ & $2 /$ & & & 40 \\
\hline & 30.0 & & & & $6 /$ & 11 & & & & 20.0 & $2 /$ & 40.0 & 28.6 & $\begin{array}{c}4 / \\
57.1 \\
\end{array}$ & & & & $6 /$ \\
\hline & $\begin{array}{l}26 / \\
65.0\end{array}$ & & $8 /$ & & $\begin{array}{c}2 / \\
20.0\end{array}$ & $\begin{array}{c}2 / \\
20.0\end{array}$ & $\begin{array}{c}5 / \\
50.0\end{array}$ & $\begin{array}{c}3 / \\
30.0\end{array}$ & $2 /$ & $4 /$ & $\begin{array}{l}0 / \\
0.0\end{array}$ & $\begin{array}{c}1 / \\
20.0\end{array}$ & $\begin{array}{c}5 / \\
71.4\end{array}$ & $\begin{array}{l}0 / \\
0.0\end{array}$ & 21 & $46 /$ & & $\begin{array}{l}5 / \\
0.8\end{array}$ \\
\hline & $\begin{array}{l}18 / \\
45.0\end{array}$ & 1.0 & & $\begin{array}{c}3 / \\
30.0 \\
\end{array}$ & $\begin{array}{c}6 / \\
60.0 \\
\end{array}$ & $\begin{array}{c}1 / \\
10.0\end{array}$ & $\begin{array}{c}3 / \\
30.0 \\
\end{array}$ & $5 /$ & 21 & $\begin{array}{c}2 / \\
40.0\end{array}$ & $\begin{array}{c}1 / \\
20.0\end{array}$ & $\begin{array}{c}2 / \\
40.0\end{array}$ & $\begin{array}{c}3 / \\
42.8 \\
\end{array}$ & $\begin{array}{c}2 / \\
28.6 \\
\end{array}$ & 21 & $9 /$ & $22 /$ & $\begin{array}{l}91 / \\
9.2 \\
\end{array}$ \\
\hline
\end{tabular}

Note: S - sensitive; R - resistant; IR - moderately resistant

Similar results regarding the determined level of antibiotic sensitivity of enterobacteria isolated from food were found in the article by T. Mahami et al. They indicated that food isolates of Enterobacteriaceae and Klebsiella showed high resistance to penicillins, macrolides and tetracyclines [28].

Among the bacteria of the family Enterobacteriaceae isolated from food, the ability to synthesize ESBL was found in 18 cultures. This amounted to $25.0 \%$ of the total number of opportunistic enterobacteria. Among the E. coli strains, $55.7 \%$ of isolates had this ability. As well as this ability had $11.1 \%$ P. vulgaris, $27.8 \%$ of $K$. pneumoniae, $5.6 \%$ of Enterobacter cloaceae.

The study found that all these strains of bacteria of the family Enterobacteriaceae with the ability to synthesize ESBL differed from other isolates resistant to at least 4 antibiotics. Among them, at least one belonged to the group of thirdgeneration cephalosporins with a broad spectrum of antibacterial action. It should be noted that 7 strains of E. coli, two strains of $P$. vulgaris and three strains of $K$. pneumoniae were characterized by resistance to 6 or more tested drugs. It should be noted that according to the results of studies cited in the article [29], it was found that $90 \%$ of ESBL strains of the genera Escherichia and Klebsiella isolated from seafood were resistant to at least one of the third-generation cephalosporins: cefotaxime, ceftazidime and cefpodoxime, and $38.46 \%$ of cultures were resistant to 5 antibiotics and belonged to the category of multiresistant.

\section{Conclusions}

Summarizing the above:

1. Samples of dairy products that did not meet microbiological standards $(60.3 \%$, from 229 - the total number of samples with deviation) were characterized by the presence of bacterium of intestinal bacillus in $24.6 \%$ of cases, Staphylococcus bacteria - in $18.8 \%$, Enterococcus - in $5.8 \%$ of cases. Their titers (average) were 
Journal of Chemistry and Technologies, 2020, 28(1), 100-112

$2.95 \pm 0.42, \quad$ respectively; $3.88 \pm 0.79$ and $2.78 \pm 0.83 \mathrm{lg}$ CFU / g of product.

2. Samples of meat products that did not meet microbiological standards (out of 229 samples $27.5 \%$ - poultry meat and by-products, $12.2 \%$ beef and beef by-products) were characterized by the presence of bacterium of intestinal bacillus in $41.7 \%$ of cases, bacteria, Staphylococcus - in $30.8 \%$, Enterococcus - in $14.3 \%$ of cases. Titers (average) of bacterium of intestinal bacillus, bacteria of the genera Staphylococcus and Enterococcus in samples of meat and poultry byproducts with deviations from the normative indicators were $4.26 \pm 0.63$, respectively; $2.86 \pm 0.42$ and $3.50 \pm 0.83 \mathrm{CFU} / \mathrm{g}$ of product, and in samples of meat and cattle by-products $3.73 \pm 1.97,2.41 \pm 0.64$ and $2.66 \pm 1.73 \mathrm{CFU} / \mathrm{g}$ of product.

3. The species composition of the sanitaryindicative microflora was represented by: 1) 7 species of bacterium of intestinal bacillus: Escherichia coli, Proteus vulgaris, P. mirabilis, Klebsiella pneumoniae, K. oxytoca, Citrobacter freundii, Enterobacter cloaceae; 2) three species of staphylococci: Staphylococcus aureus, S. epidermidis, S. saprophyticus, 3) two species of enterococci: Enterococcus faecium and E. faecalis.

4. The presence of MRSA and MRSE among staphylococci was shown for the first time. The most resistant isolated strains of staphylococci were to antibiotics of the penicillin series ampicillin and oxacillin - respectively 79.6 and $68.5 \%$ of cultures. In addition, they had a high level of resistance to macrolides and tetracyclines. 10 strains of $S$. aureus and 7 strains of $S$. epidermidis was classified as MRSA and MRSE, respectively. Among them were those characterized by resistance to modern $\beta$-lactam antibiotics: imipenem (1 strain), cefotaxime (5 cultures), ceftriaxone (7 isolates), ceftazidime (7 strains), amoxicillin/clavulanic acid (7 cultures). Five were resistant to vancomycin and three were resistant to linezolid.

5. Ampicillin, ceftriaxone, ciprofloxacin, tetracycline, and doxycycline were the least effective against the isolated enterococcal strains. Only $33.3 \%$ of all tested isolates of the genus Enterococcus were sensitive to them. Among the isolated cultures of enterococci, there were strains that had resistance to 5-6 or more drugs simultaneously.

6 . The highest percentage of strains resistant to penicillin drugs was registered among members of the Enterobacteriaceae family. Thus, resistance to ampicillin was found in $86.1 \%$ of enterobacterial isolates, to oxacillin in $84.7 \%$, to amoxicillin/clavulanate in $75.0 \% .60 .0 \%$ of cultures were resistant to nitrofurantoin, $66.7 \%$ and $72.2 \%$ to tetracycline and doxycycline. The largest number of insensitive strains was found among isolates of the genus Proteus and Klebsiella.

7. The ability to synthesize ESBL was first shown in enterobacteria isolated from food. Among the bacteria of the family Enterobacteriaceae isolated from food, the ability to ESBL synthesize was found in 18 cultures. This amounted to $25.0 \%$ of the total number of opportunistic enterobacteria. Among E. coli strains, $55.7 \%$ of isolates, P. vulgaris - $11.1 \%$, K. pneumoniae - $27.8 \%$, Enterobacter cloaceae $5.6 \%$ of cultures had this ability.

8. The sensitivity of bacteria of the Enterobacteriaceae family to antibiotics was determined for the first time. ESBL strains of bacteria of the family Enterobacteriaceae differed from other isolates by resistance to at least 4 antibiotics. Among them, at least one belonged to the group of third-generation cephalosporins. 7 strains of $E$. coli, two strains of $P$. vulgaris and three strains of K. pneumoniae were characterized by resistance to 6 or more tested drugs. They are classified as multidrug-resistant.

Therefore, from the above it is clear that food can be one of the sources of entry into the human body of sanitary-indicative microflora. In addition to the ability to cause an infectious process due to the synthesis of various pathogenic factors, including enzymes, toxins, adhesives, etc. There is interstitial, intraspecific and intergeneric transfer of antibiotic resistance genes in the sanitaryindicative microflora. This contributes to the emergence of cultures with acquired resistance to antibiotics and the formation of multi-resistant variants.

Elimination of such strains from the human body will present some difficulties, because they do not belong to the class of xenobiotics and can not be eliminated from the body by glutathione, glucuronide and other biochemical pathways [33]. There is a high probability of their retention in the human body and the emergence of various diseases against their background.

Therefore, constant monitoring of isolates of enterobacteria capable of synthesis of ESBL in the environment, and especially in food products according to the method outlined in the article, as well as taking measures to limit the further spread of these species of opportunistic pathogens is essential to improve health of population in many countries around the world. 


\section{Bibliography}

[1] The growth gerformance, meat quality, and gut bacteria of broilers raised with or without antibiotics and green tea powder / X. Chen, W. Zhu, X. Liu, T. Li // Journal of Applied Poultry Research. - 2019. - Vol. 28, N 3. - pp. 712-721.

[2] Study of the antibiotic residues in poultry meat in some of the EU countries and selection of the best compositions of lactic acid bacteria and essential oils against Salmonella enterica / Bartkiene E., M. Ruzauskas, V. Bartkevics, I. Pugajeva // Poultry Science. - 2020. pp. 1-12.

[3] Павлів О.В. Санітарно-гігієнічні проблеми залишкових кількостей антибіотиків у продуктах тваринництва / О.В. Павлів // Науковий вісник ЛНУВМБТ ім. С.3. Гжицького. - 2012. - pp. 362-365.

[4] Antibiotic residues in meat, milk and aquatic products in Shanghai and human exposure assessment / H. Wang, L. Ren, X. Yu, J. Hu // Food Control. - 2017. - Vol. 80, pp. 217-225.

[5] Normanno G. Occurrence, characterization and antimicrobial resistance of enterotoxigenic Staphylococcus aureus isolated from meat and dairy products / G. Normanno // International Journal of Food Microbiology. - 2007. - Vol. 115, N 3. - P. 290-296.

[6] Горюк Ю. В. Біотипи золотистого стафілококу, які виділені з молока сирого та молочних продуктів домашнього виробництва, та їх чутливість до антибактеріальних препаратів / Ю. В. Горюк // Проблеми зооінженерії та ветеринарної медицини. - 2016. - T. 32, N.2. - C. 185-190.

[7] Nawras N. J. Isolation and biotyping of Staphylococcus aureus from white cheese in basrah local markets / N. J. Nawras // Bas. J. Vet. Res. - 2011. - Vol. 88, N 10. - P.5665.

[8] Антибіотикорезистентність польових штамів мікроорганізмів / М. Д. Кучерук, Д. А. Засекин, Л. М. Виговська, В. О. Ушкалов // Біоресурси і природокористування. - 2018. - Т.10, N 5-6. - С.205217.

[9] Мікробіологічне забруднення молока і молочних продуктів за субклінічних маститів у корів та шляхи їх попередження / Г. Ф. Риженко, О. І. Горбатюк, В. O. Андріящук, О. В. Жовнір, Т. М. Уховська, С. М. Тютюн, П. П. Каменчук // Ветеринарна біотехнологія. 2016. - №29. - C. 233-241.

[10] Founou L. L. Antibiotic Resistance in the Food Chain: A Developing Country-Perspective / L. L. Founou, R. C. Founou, S. Y. Essack // Front Microbiol. - 2016. - Vol. 7:1881.

[11] Короткевич Ю. В. Анализ резистентности к антибиотикам энтеробактерий и энтерококков, выделяемых из пищевых продуктов / Ю. В. Короткевич // Вопросы питания. - 2016. - Т. 85, № 2. - C.5-13

[12] ГОСТ 9225-84 Молоко и молочные продукты. Методы микробиологического анализа. - М.: Стандартинформ, 2009. - 16 с.

[13] ГОСТ 30347-2016 Молоко и молочные продукты. Методы определения Staphylococcus aureus. - M: Стандартинформ, 2016. - 16 с.

[14] ДСТУ ISO 6887-1:2003 Мікробіологія харчових продуктів і кормів для тварин. Готування досліджуваних проб, вихідної суспензії та десятикратних розведень для мікробіологічного дослідження. Частина 1. Загальні правила готування вихідної суспензії та десятикратних розведень

[15] ГОСТ Р 54354-2011. Мясо и мясные продукты. Общие требования и методы микробиологического анализа. - М.: Стандартинформ, 2013. - 42 с.

[16] Эльдельштейн М.В. Выявление $\beta$-лактамаз расширенного спектра у грамотрицательных бактерий с помощью фенотипических методов / М.В.Эльдельштейн // Клиническая микробиология и антимикробная терапия. - 2001. - Т.3, №2. - С. 183189.

[17] Marimuthu K. Screening for methicillin-resistant Staphylococcus aureus... all doors closed / K. Marimuthu, S. Harbarth // Current Opinion in Infectious Diseases. - 2014. - Vol. 27. - N4, P.356-362.

[18] Гостев В. В. Антибиотикорезистентность метициллинорезистентных Staphylococcus aureus / В.В. Гостев, О.С. Калиногорская, Л.Н. Попенко, Т.В. Черненькая // Антибиотики и химиотерапия. 2015. - T. 60, №1-2. - C.3-9.

[19] Khan A. Current and future treatment options for community-associated MRSA infection / A. Khan, B. Wilson, I.Gould // Expert Opinion on Pharmacotherapy. - 2018. Vol. 19. - N5, P. 457-470.

[20] Zheng X. Combination antibiotic exposure selectively alters the development of vancomycin intermediate resistance in Staphylococcus aureus / X. Zheng, A. Berti, S. McCrone, M. Roch // Antimicrobial Agents and Chemotherapy. - 2018. - Vol. 62, N2. - P. 100-117.

[21] Rybak J. Early experience with tedizolid: Clinical efficacy, pharmacodynamics, and resistance / J. Rybak, K. Marx, C. Martin // Pharmacotherapy. - 2014. Vol. 34, N 11. - P. 1198-1208.

[22] Oh E. Antioxidant-based synergistic eradication of methicillin-resistant Staphylococcus aureus (MRSA) biofilms with bacitracin / Oh, E., Bae, J., Kumar, A., Choi, H., \& Jeon, B. // International Journal of Antimicrobial Agents. - 2018. - Vol. 52, N1. - P. 96-99.

[23] Para R. Microbial etiology in hospitalized North Indian adults with community-acquired pneumonia / R. Para, B. Fomda, R. Jan, S. Shah // Lung India: Official Organ of Indian Chest Society. - 2018. - Vol. 35, N2. - P. 108-115.

[24] Magiorakos A.-P. Multidrug-resistant, extensively drugresistant and pandrug-resistant bacteria: an international expert proposal for interim standard definitions for acquired resistance / A.-P. Magiorakos, A. Srinivasan, R.B. Carey, Y. Carmeli, M. E. Falagas // Clinical Microbiology and Infection. - 2012. - Vol. 18, N. 3. - P. 268-281.

[25] Минаева Л. П. Проблемы безопасности мяса и продуктов из него при их загрязнении антибиотиками / Л. П. Минаева // Вопросы диетологии. - 2017. - Т.7, №4. - С.31-34.

[26] Татарникова Н. А. Антибиотики в пищевых продуктах / Н. А. Татарникова, О. Г. Мауль // Известия ОГАУ. - 2014. - №5 (49). - С.208-2011.

[27] Мережко O. Е. Формирование устойчивости микроорганизмов при внесении антибиотиков в корма / О. Е. Мережко, Н. Б. Станишевская // Известия ОГАУ. - 2015. - №2 (52). - С.174-176.

[28] Mahami T. Microbial food safety risk to humans associated with poultry feed: the role of irradiation / T. Mahami, W. Togby-Tetteh, D. Kottoh, L. AmoakoahTwum // International journal of food science. - 2019Vol.1. - P. 1-8.

[29] Sanjit S. A. Multiple antibiotic-resistant, extended spectrum- $\beta$-Lactamase enterobacteria in fresh seafood / (ESBL)-producing 
Journal of Chemistry and Technologies, 2020, 28(1), 100-112

S.A. Sanjit, M. Lekshmi, S. Prakasan, B. Nayak // Microorganisms. - 2017. - Vol. 30, N 5. - P. 37-49.

[30] European Committee on Antimicrobial Susceptibility Testing et.al. Breakpoint tables for interpretation of MICs and zonediameters. Version 5.0, January. 2015.

[31] Igbinosa E.0. Detection of Methicillin-Resistant Staphylococci Isolated from Food Producing Animals: A Public Health Implication / E.O. Igbinosa, A. Beshiru, L.U. Akporehe, A.G.Ogofure // Veterunary Sciences. - 2016. - Vol. 3, N3. - P. 2-14.

[32] Dweba C.C. Methicillin-resistant Staphylococcus aureus: livestock-associated, antimicrobial, and heavy metal resistance/ C.C.Dweba, O.T. Zishiri, M.E. El Zowalaty // Infect Drug Resist. - 2018. - Vol.11. - P. 2497-2509.

[33] Теоретичні аспекти створення харчових гідрогелів з глюкуроновою кислотою / Є. А. Поливанов, Н. В. Кондратюк, О. Ю. Вієнко, І. П. Гончаренко // Вісник НТУ «ХПІ», Серія: Інноваційні дослідження у наукових роботах студентів. - 2020. - Т.5, N 1359. C. 86-91.

\section{References}

[1] Chen, X., Zhu, W., Liu, X., Li, T. (2019). The growth gerformance, meat quality, and gut bacteria of broilers raised with or without antibiotics and green tea powder. Journal of Applied Poultry Research, 28(3), 712-721. http://doi.org/10.3382/japr/pfz023

[2] Bartkiene, E., Ruzauskas, M., Bartkevics, V., Pugajeva, I. (2020). Study of the antibiotic residues in poultry meat in some of the EU countries and selection of the best compositions of lactic acid bacteria and essential oils against Salmonella enterica. Poultry Science, 1-12 http://doi.org/10.1016/j.psj.2020.05.002

[3] Bartkiene, E., Ruzauskas, M., Bartkevics, V., Pugajeva, I. (2020). Study of the antibiotic residues in poultry meat in some of the EU countries and selection of the best compositions of lactic acid bacteria and essential oils against Salmonella enterica. Poultry Science, 1-12 http://doi.org/10.1016/i.psj.2020.05.002

[4] Wang, H., Ren, L., Yu, X., Hu, J. (2017). Antibiotic residues in meat, milk and aquatic products in Shanghai and human exposure assessment. Food Control. 80, 217225. http://doi.org/10.1016/i.foodcont.2017.04.034

[5] Normanno, G. (2007). Occurrence, characterization and antimicrobial resistance of enterotoxigenic Staphylococcus aureus isolated from meat and dairy products. International Journal of Food Microbiology. 115(3), 290-296.

https://doi.org/10.1016/i.ijfoodmicro.2006.10.049

[6] Goriuk Yu. V. (2016). [Staphylococcus aureus biotypes isolated from raw milk and home-made dairy products and their sensitivity to antibacterial drugs]. Problemy zooinzhenerii ta veterynarnoi medytsyny - The problems of zooengineering and veterinary medicine, 32(2), 185190 (in Ukrainian).

[7] Nawras, N. J. (2011). Isolation and biotyping of Staphylococcus aureus from white cheese in basrah local markets. Bas. J. Vet. Res. 88(10), 56-65. https://doi.org/10.33762/bvetr.2011.55025

[8] Kucheruk, M. D., Zasekyn, D. A., Vyhovska, L. M., Ushkalov, V. O. (2018). [Antibiotic resistance of field strains of microorganisms]. Bioresursy $i$ pryrodokorystuvannia. - Bioresources and nature management, 10(5-6), 205-217 (in Ukrainian).

[9] Ryzhenko, H. F., Horbatiuk, O. I., Andriiashchuk, V. O., Zhovnir, O. V. (2016). [Microbiological contamination of milk and dairy products in subclinical mastitis in cows and ways to prevent them]. Veterinary biotechnology, 29, 233-241.

[10] Founou, L. L. (2016). Antibiotic Resistance in the Food Chain: A Developing Country-Perspective. Front Microbiol. 7 , 1881. https://doi.org/10.3389/fmicb.2016.01881

[11] Korotkevych, Yu. V. (2016). [Analysis of antibiotic resistance of enterobacteria and enterococci isolated from food]. Voprosy pitanija. - Nutrition issues, 85(2), 513.

[12] Euro-Asian Council for Standardization, Metrology and Certification (2009). [Milk and dairy products. Microbiological analysis methods]. (GOST 9225-84). Moskow, Standartinform (in Russian).

[13] Euro-Asian Council for Standardization, Metrology and Certification (2016). [Milk and dairy products. Methods for the determination of Staphylococcus aureus]. [GOST 30347-2016). Moskow, Standartinform (in Russian).

[14] State Committee for Technical Regulation and Consumer Policy of Ukraine. (2003). [Microbiology of food and animal feed. Preparation of test samples, initial suspension and ten-fold dilutions for microbiological examination. Part 1. General rules for preparation of the initial suspension and ten-fold dilutions]. (DSTU ISO 6887-1:2003). Kyiv, Derzhpozhyvstandart Ukraine (in Ukrainian).

[15] Federal Agency on Technical Regulating and Metrology (2011). [Meat and meat products. General requirements and methods of microbiological analysis]. (GOST R P 54354-2011). Moskow, Standartinform (in Russian).

[16] Jejdel'shtejn, M.V. (2001) Vyjavlenie $\beta$-laktamaz rasshirennogo spektra u gramotricatel'nyh bakterij $\mathrm{s}$ pomoshh'ju fenotipicheskih metodov. Klinicheskaja mikrobiologija i antimikrobnaja terapija, 3(2), 183-189 (in Russian).

[17] Marimuthu, K., \& Harbarth, S. (2014). Screening for methicillin-resistant Staphylococcus aureus. Current Opinion in Infectious Diseases, 27(4), 356-362. https://doi.org/10.1097/QC0.0000000000000081

[18] Gostev, V. V., Kalinogorskaja, O. S., Popenko, L. N., Chernen'kaja, T. V., Naumenko, Z. S., Voroshilova, T. M., Zaharova, J. A., Hohlova, O. E., Kruglov, A. N., Ershova, M. G., Molchanova, I. V., \& Sidorenk, S. V. (2015). Antibiotikorezistentnost' meticillinorezistentnyh Staphylococcus aureus, cirkulirujushhih v Rossijskoj Federacii. Antibiotiki i Himioterapija, 60(1-2), 3-9 (in Russian).

[19] Khan, A., Wilson, B., \& Gould, I. (2018). Current and future treatment options for community-associated MRSA infection. Expert Opinion on Pharmacotherapy, 19(5), 457-470.

doi: 10.1080/14656566.2018.1442826

[20] Zheng, X., Berti, A., McCrone, S., Roch, M., Rosato, A., Rose, W., \& Chen B. (2018). Combination antibiotic exposure selectively alters the development of vancomycin intermediate resistance in Staphylococcus aureus. Antimicrobial Agents and Chemotherapy, 62(2), 10-17. https://doi.org/10.1128/AAC.02100-17

[21] Rybak, J., Marx, K., \& Martin, C. (2014). Early experience with tedizolid: Clinical efficacy, pharmacodynamics, and resistance. Pharmacotherapy, 34(11), 1198-1208. https://doi.org/10.1002/phar.1491 
Journal of Chemistry and Technologies, 2020, 28(1), 100-112

[22] Oh, E., Bae, J., Kumar, A., Choi, H., \& Jeon, B. (2018). Antioxidant-based synergistic eradication of methicillin-resistant Staphylococcus aureus (MRSA) biofilms with bacitracin. International Journal of Antimicrobial Agents. 52(1), 96-99 https://doi.org/10.1016/j.ijantimicag.2018.03.006

[23] Para, R., Fomda, B., Jan, R., Shah, S., \& Koul, P. (2018). Microbial etiology in hospitalized North Indian adults with community-acquired pneumonia. Lung India: Official Organ of Indian Chest Society, 35(2), 108-115. https://doi.org/10.4103/lungindia.lungindia_288_17

[24] Magiorakos, A.-P., Srinivasan, A., Carey, R. B., Carmeli, Y., Falagas, M. E., Giske, C. G., Harbarth, S., Hindler, J. F., Kahlmeter, G., Olsson-Liljequist, B., Paterson, D. L., Rice, L. B., Stelling, J., Struelens, M. J., Vatopoulos, A., Weber, J. T. Monnet D. L. (2012). Multidrug-resistant, extensively drug-resistant and pandrug-resistant bacteria: an international expert proposal for interim standard definitions for acquired resistance. Clinical Microbiology and Infection, 18(3), 268-281. https://doi.org/10.1111/j.1469-0691.2011.03570.x.

[25] Minaeva, L. P. (2017). [The safety problems of meat and products from it when they are contaminated with antibiotics]. Voprosy dietologii - Nutritional Issues. 7(4), 31-34.

[26] Tatarnikova, N. A. (2014). [Antibiotics in food]. Izvestija OGAU. 5(49), 208-211.

[27] Merezhko, O. E. (2015). [The formation of the resistance of microorganisms when antibiotics are added to feed]. Izvestija OGAU. 2 (52). 174-176.
[28] Mahami T., Togby-Tetteh W., Kottoh D., AmoakoahTwum L. (2019). Microbial food safety risk to humans associated with poultry feed: the role of irradiation. International journal of food science. https://doi.org/10.1155/2019/6915736

[29] Sanjit S. A., Lekshmi M., Prakasan S., Nayak B. B., Kumar S. (2017). Multiple antibiotic-resistant, extended spectrum- $\beta$-Lactamase (ESBL)-producing enterobacteria in fresh seafood. Microorganisms, 5(3). 30. https://doi.org/10.3390/microorganisms5030053

[30] European Committee on Antimicrobial Susceptibility Testing et.al. Breakpoint tables for interpretation of MICs and zonediameters. Version 5.0, January. 2015.

[31] Igbinosa, E. O., Beshiru, A., Akporehe, L. U., Ogofure, A. G. (2016) Detection of methicillin-resistant Staphylococci isolated from food producing animals: A public health implication. Vet Sci. 3(3). 14. https://doi.org/10.3390/vetsci3030014

[32] Dweba, C. C., Zishiri, O. T., El Zowalaty, M. E. (2018). Methicillin-resistant Staphylococcus aureus: livestockassociated, antimicrobial, and heavy metal resistance.Infect Drug Resist. 11, 2497-2509. https://doi.org/10.2147/IDR.S175967

[33] Polyvanov, Ye. A., Kondratiuk, N. V., Viienko, O. Yu., Honcharenko, I. P. (2020). [Theoretical aspects of creating food hydrogels with glucuronic acid]. Visnyk NTU «KhPI», Seriia: Innovatsiini doslidzhennia $u$ naukovykh robotakh studentiv, 5(1359), 86-91. https://doi.org/10.20998/2220-4784.2020.05.13 